\title{
Change in fish and benthic communities in Belizean patch reefs in and outside of a marine reserve, across a parrotfish capture ban
}

\author{
T. R. McClanahan*, N. A. Muthiga \\ Wildlife Conservation Society, Global Marine Program, Bronx, NY 10460, USA
}

\begin{abstract}
The role of a marine reserve and fisheries regulations in restoring fish populations on reefs disturbed by climate impacts was evaluated. Eight patch reefs, divided equally between nofishing and fished zones in the remote Glover's Reef atoll lagoon, were studied for $22 \mathrm{yr}: 13 \mathrm{yr}$ before and $9 \mathrm{yr}$ after a ban on parrotfish capture. Findings indicate that the main effect of the fisheries closure was the recovery of targeted carnivorous species, notably snappers, jacks, and groupers. Recovery continued for most of the time series, including the later period when parrotfish capture was banned. Parrotfish abundance slowly declined in both management zones and across the ban period. The loss occurred for both small non-fished species, such as the striped parrotfish Scarus iserti, and for larger fished species, such as the stoplight Sparisoma viride and red-band parrotfish Sparisoma aurofrenatum. Consequently, parrotfish abundance appeared to be controlled by the ecology of these patch reefs rather than fishing mortality. We suggest that the high and persistent cover of late-successional algae reduces the renewal rates of algae, which had negative consequences for all studied parrotfish populations. Low ocean currents and physical energy in the lagoon appeared to promote algal persistence. Thus, parrotfish bans may be more effective in promoting reef recovery in environments that promote rapid algal turnover. Fisheries regulations are unlikely to rapidly restore hard corals on these patch reefs, which have slowly transitioned to algal dominance since first described in 1970.
\end{abstract}

KEY WORDS: Herbivory · Marine reserves $\cdot$ Species restrictions $\cdot$ BACI design $\cdot$ Climate change · Caribbean

\section{INTRODUCTION}

Reef ecosystems in the Caribbean are experiencing multiple human and natural disturbances that are causing major basin-wide changes in their ecology and threatening their existence (Muñiz-Castillo et al. 2019, Siegel et al. 2019). Many Caribbean reefs are now dominated by fleshy or frondose brown algae that is causing reductions in hard coral and declines in calcium carbonate deposition (Roff \& Mumby 2012, Bruno et al. 2014, Perry et al. 2015, Suchley et al. 2016, Precht et al. 2019). These gross changes are also associated with changing community composition, as taxa with competitive life histories are replaced by opportunistic and stress resistant taxa

\footnotetext{
${ }^{*}$ Corresponding author: tmcclanahan@wcs.org
}

(Edmunds et al. 2014, Darling et al. 2019). These changes pose a major threat to coral reef health and persistence. Causes of the changes are controversial but include factors such as disease, bleaching, the loss of fish and sea urchin grazers, increased nutrients and sediments, and warm-water disturbances (W. F. Precht et al. unpubl.). A major question for reef ecology and fisheries management is how changes differ within no-fishing and fishing zones over time (Newman et al. 2006, McClanahan et al. 2011a,b, Toth et al. 2014, Cox et al. 2017, Tewfik et al. 2017, Suchley \& Alvarez-Filip 2018) and the subsequent effects on target species, their prey and ecological processes (Mumby 2009, Babcock et al. 2013, Steneck et al. 2018).

() The authors 2020. Open Access under Creative Commons by Attribution Licence. Use, distribution and reproduction are unrestricted. Authors and original publication must be credited. 
Various disturbances including thermal stress, disease, and human coastal development are killing hard corals (Eakin et al. 2010, Suchley \& AlvarezFilip 2018). The space opened by their death is subsequently colonized by various algae and soft corals, which are modified by predation and nutrification (McClanahan et al. 2002, Rasher et al. 2012, Pawlik et al. 2016). Some of these colonizing algae may be non-preferred or unpalatable and therefore repel some herbivorous fishes (McClanahan et al. 2000, Adam et al. 2018, Smith et al. 2018). The consequences of the change to algal-dominated reefs include reduced recruitment of corals, reduced abundance of herbivorous fishes and a reduction in their rates of herbivory, reduced abundance of coraleating fishes, and variable responses among predators of invertebrates (Adam et al. 2015). Changes appear to be persistent, such that many stony coral populations show limited recovery after disturbance (Cox et al. 2017). Some investigators attribute this lack of recovery to chronic local disturbances, with little abatement; others suggest basin-wide thermal and nutrient problems have accelerated beyond a mitigating threshold, thus tilting the coral-algae imbalance in favor of various algae (Pawlik et al. 2016, De Bakker et al. 2017). This shift to algal dominance is widespread and jeopardizes the healthy functioning and growth of Caribbean reefs (Perry et al. 2015).

Fisheries investigators and managers in Belize have been actively addressing these problems through the establishment of monitoring and management via marine reserves and fisheries regulations intended to abate the decline (Cox et al. 2013, 2017). In the face of reef health decline, and dominance of algae, a ban on parrotfish capture was initiated by law and in practice by the Belize Fisheries Department in 2009 (Government of Belize 2009). Thus, our small-scale monitoring system of patch reefs in and outside of Glover's Reef Marine Reserve can evaluate the outcome of these restrictions (McClanahan et al. 2011a). Monitoring began in 1996, shortly after the establishment of the no-take marine reserve. This study, therefore, investigates ecological responses to the dual and interactive role of no-take marine reserves and the 2009 ban on parrotfish capture.

Banning the capture of parrotfish could promote herbivory, lower algal abundance, and increase hard coral, particularly outside of marine reserves (Bozec et al. 2016, Steneck et al. 2018). However, some empirical studies suggest that coral-algal changes in Belizean and Mesoamerican marine reserves have been small or undetectable and not clearly driven by herbivory (McClanahan et al. 2011a, Cox et al. 2017,
Suchley et al. 2016, Suchley \& Alvarez-Filip 2018). For example, reefs dominated by Acropora spp. in the 1970s but subsequently impacted by disease and bleaching turned into coral rubble colonized by algae and small colonies of Porites spp. with no measurable effects on fish abundance (McClanahan \& Muthiga 1998, Huntington et al. 2010). Conversely, a number of targeted fish populations increased in higher complexity patch reefs dominated by Orbicella spp. (McClanahan et al. 2011a). Thus, management outcomes are likely to vary with reef habitat.

Our study is restricted to repeat surveys of 8 Orbicella spp.-dominated patch reefs divided equally between a well-enforced, nationally-designated notake marine reserve and a restricted-fishing zone. Our study is an effort to determine the effects of the parrotfish ban by examining the outcomes in a Before-After-Control-Impact (BACI) design where surveys were undertaken in the $13 \mathrm{yr}$ before and the 9 yr after the ban. We asked if the trophic cascade model of reduced fishing mortality and recovery of parrotfish would increase herbivory, turf and calcifying algae, and hard coral, while decreasing erect frondose algae (Bellwood et al. 2004). The specific hypotheses tested were whether the fisheries closure and the ban on parrotfish capture promoted (1) an increase in parrotfish, (2) an increase in rates of herbivory, (3) an increase in calcifying and turf algae, and hard coral accompanied by a decrease in erect frondose algae, and (4) a change in fishing effort that decreases the abundance of less targeted fish species. These responses were predicted to occur shortly after the 2009 parrotfish ban and to be greater in fished than unfished reefs.

\section{MATERIALS AND METHODS}

\subsection{Study sites}

Glover's Reef $\left(16^{\circ} 44^{\prime} \mathrm{N}, 87^{\circ} 48^{\prime} \mathrm{W}\right)$ is the most southerly of 3 Belizean atolls and is located offshore approximately $15 \mathrm{~km}$ east of the barrier reef (Fig. 1). The atoll covers 13200 ha and has 6 sandy cays linked by an emergent windward reef crest. The reef crest is broken by 3 windward tidal channels, where water flows between the lagoon and open sea. The lagoon contains $\sim 850$ patch reefs of variable sizes and the study was undertaken in similarly sized reefs $\left(\sim 1000 \mathrm{~m}^{2}\right)$, with shallow tops (1-2 $\mathrm{m}$ ) that have been monitored since 1996 (McClanahan et al. 2001, 2011a). The outer edge of the atoll drops to $>500 \mathrm{~m}$ in depth less than a kilometer from the crest, while the central lagoon 

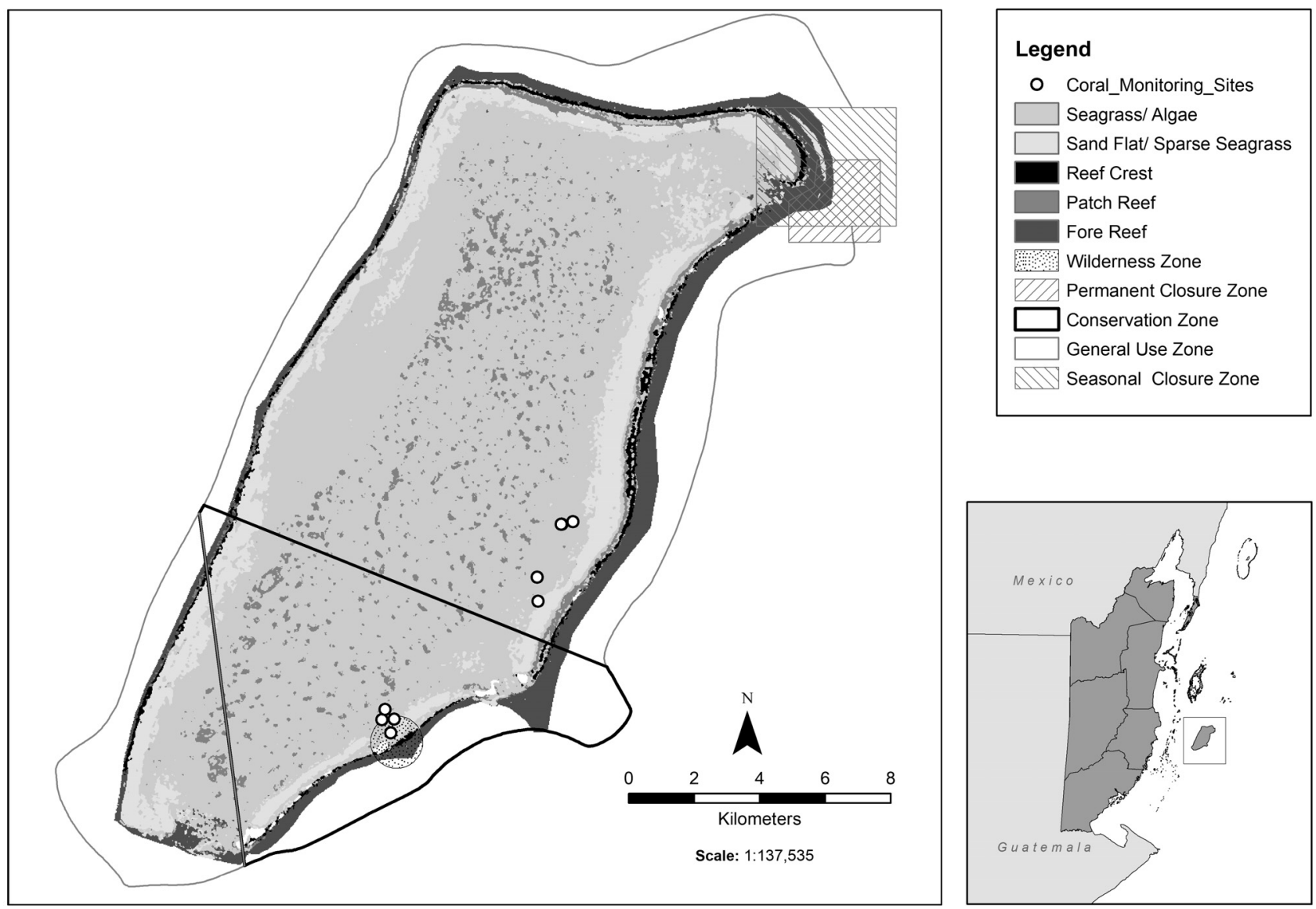

Fig. 1. Study sites in Glover's Reef atoll lagoon, Belize

depth seldom exceeds $20 \mathrm{~m}$. The currents in the atoll are relatively weak and controlled by local wind and tidal forces ( $\sim .18 \mathrm{~m}$ spring tidal range) especially in the southern portion of the atoll (McClanahan \& Karnauskas 2011). Sea surface temperatures and nutrients measured in previous studies showed no significant differences between managed areas (McClanahan et al. 2011a). A number of seasonal thermal stresses, resultant coral bleaching, and also diseases occurred during the 1996-2018 study period, with notable thermal anomalies in 2005, 2010, and 2016 (Muñiz-Castillo et al. 2019). Despite the thermal stresses, fish populations increased and other ecological processes changed in the studied patch reefs inside the marine reserve, while fewer changes were observed outside (McClanahan et al. 2011a).

The southern end of the atoll was legally gazetted as a no-take marine reserve of $70.8 \mathrm{~km}^{2}$ in 1993 and enforcement was initiated by 1995 when a field station was built on Middle Cay island, shortly before the first data in this study were collected. The southern quarter of the atoll is legally referred to as the Conservation Zone (CZ), where fishing is prohibited, and the northern $3 / 4$ is the General Use Zone (GUZ), where spear fishing is the dominant form of fishing (McClanahan et al. 2011a). Management rules are enforced by the Belize Fisheries Department patrol unit permanently based at Middle Cay adjacent to the CZ. Eight patch reefs were sampled during each sampling period, of which half were inside and half outside the CZ (Fig. 1).

\subsection{Benthic cover and algal biomass}

Benthic cover on each patch reef was assessed by the line intercept method for three $10 \mathrm{~m}$ line transects per reef. Transects were laid parallel to the patch reef's windward northeast edge at 3 locations: on the edge (the transition from the sand to patch reef), at the shoulder (shallow windward edge), and at the center. Substrate cover was recorded by species for stony corals, by genus for fleshy and calcareous algae, and by gross functional groups for encrusting coralline algae, branching coralline algae, algal turf, seagrass, sand, sponge, soft coral, zooanthids, and 
microalgae (cyanobacteria and diatoms). All benthic organisms $3 \mathrm{~cm}$ or larger directly under the draped line were measured and recorded.

\subsection{Fish population estimates}

Visual counts were carried out using the Discrete Group Sampling (DGS) method, where a limited number of species are sampled during a single sampling period. The shallowness and small size of patch reefs did not permit the use of standard belt transects; therefore, 5 min search intervals or roving methods were used to sample fish. Roving methods have been shown to be efficient and increase the detection of species relative to belt transects (Beck et al. 2014). During the 35 min sampling periods, the investigator swam haphazardly around each patch reef, and recorded the number of species and individuals in each group over a 5 min interval per group, recorded with stopwatch. Individuals less than $3 \mathrm{~cm}$ were not counted.

Species were separated into discrete groups based on their taxonomy and position in the reef or water column. Each of the following 7 discrete family/ functional groups were assessed separately: Group 1: Chaetodontidae (butterflyfishes) and Pomacanthidae (angelfishes); Group 2: Acanthuridae (surgeonfishes); Group 3: Haemulidae (grunts), Sparidae (porgies), and Lutjanidae (snappers); Group 4: Scarinae (parrotfishes); Group 5: Labridae (wrasses); Group 6: Spyringnea (barracuda), Balistidae (triggerfish), Aulostomidae (trumpetfish), Carangidae (jacks), and Chromis spp.; Group 7: Serranidae (groupers) and territorial benthic-attached pomacentrids (damselfishes). For some analyses, groupers, barracuda, and jacks were further pooled into a piscivores group. Parrotfish were counted in 2 groups: a small parrotfish group, composed mostly of the striped parrotfish Scarus iserti and juveniles of other species $<15 \mathrm{~cm}$, and a large parrotfish group composed of all species with body sizes $>15 \mathrm{~cm}$.

\subsection{Herbivory assays}

Herbivory rates on patch reefs were studied using a seagrass Thalassia testudinum assay. Seagrass blade tips were collected and visually inspected to avoid pre-bitten or epiphyte-covered samples. Seagrass blades were cut to a standard length of $9 \mathrm{~cm}$ and clippings held by weighted clothespins attached at $\sim 2 \mathrm{~m}$ intervals to thin nylon lines. Nine clippings were positioned in each zone (edge, shoulder, and center), for a total of 27 clippings per reef. Assays were left for $24 \mathrm{~h}$ before being recovered to determine the number of bites, the amount of seagrass bitten (to the closest $0.5 \mathrm{~cm}$ ), and, based on bite scar characteristics, whether fish or sea urchin were responsible for the bites, (Hay 1984, McClanahan et al. 1994). This herbivory assay method is biased towards greater herbivory by macro-algae feeding species; it underestimates herbivory by some groups such as damselfish, excavating parrotfish, and sea urchins, and does not measure herbivory for some sucking and scraping species such as surgeonfish.

\subsection{Data analyses}

The study is based on a BACI design where the periods before and after the 2009 parrotfish capture ban were compared, as well as the fishing (GUZ) and no-fishing (CZ) management zones. Prior to choosing statistical tests, data were evaluated for the assumptions of normality and equal variance with raw data and square-root and logit transformations. Some data passed these tests, but most did not, depending on the measurement and pooling of data. For example, numbers of fish species and benthic cover groups were normally distributed and therefore a 2-way ANOVA with interactions was applied. Fish evaluated at the family/functional and species level were not normally distributed. Therefore, Kruskal-Wallis tests were used to test for differences between time periods and management zones. To evaluate the overall changes in the fish communities at the species and family/functional group levels, a principal component analysis (PCA) was performed, separating the sites and times by period and management zone. PCA ordination was used because the community data was unconstrained and had a short gradient with few zeroes (Legendre \& Gallagher 2001).

Recruitment of fish was evaluated to determine its potential influence on the observed temporal patterns and if there was synchrony among species that might reflect environmental forcing. Recruitment was defined as a positive $>2$ SD deviation from the mean in abundance. Changes in the abundance of the dominant 25 species (92\% of observations) were evaluated as variation from the species' full $25 \mathrm{yr}$ time series mean. To more easily compare species, we standardized abundance to a range of $\pm 3 \mathrm{SD}$. The species' standardized annual mean was subtracted from the overall mean and plotted against time. 
Changes in coral cover and species composition were evaluated by comparing the 3 sampling dates prior to and 3 dates after the parrotfish ban in 2009. The earlier part of the time series was strongly affected by the 1998 ENSO and therefore we restricted our evaluation to after 2004. There were also less severe thermal stress periods in 2010 and 2016 that could potentially affect corals, but most of the decline in Acropora spp. due to disease and bleaching occurred prior to 2004 (McClanahan et al. 2011a).

\section{RESULTS}

\subsection{Fish populations}

The total number of parrotfish was higher in the GUZ than the CZ and declined in both locations over time (Table 1). These differences were largely due to small parrotfish, including striped parrotfish and juveniles of other species (Table 1). The number of large parrotfish was, however, not different between the $\mathrm{CZ}$ and the GUZ, and declined over time and after the capture ban. There were no differences between management zones in the total densities of fish, wrasses, butterflyfish, or angelfish; however, damselfish were more abundant in the GUZ than the CZ. Increases over time were evident for many functional/family groups targeted by fishers, but not parrotfish (Figs. 2 \& 3a). The total density of fish, as well as the number of snappers, piscivores, and angelfish increased in the $\mathrm{CZ}$ before and after the parrotfish capture ban. Angelfish numbers also increased in the GUZ after the ban but were still about half the densities found in the CZ. Number of fish species increased in the CZ and GUZ over time but most of this change occurred prior to the 2009 ban (Fig. 4).

Table 1. Mean \pm SE of numbers of fish, grouped by family/functional groups, observed per 5 min before and after the parrotfish capture ban in the Conservation and General Use Zones on Glover's Reef. Results of Kruskal-Wallis tests comparing periods and management zones are presented, as well as the 2-way ANOVA analysis for management, period and their interaction (management $\times$ period)

\begin{tabular}{|c|c|c|c|c|c|c|c|c|}
\hline \multirow[t]{2}{*}{ Management } & \multirow[t]{2}{*}{ Fish group } & \multirow[t]{2}{*}{ Pre-ban } & \multirow[t]{2}{*}{ Post-ban } & \multicolumn{2}{|c|}{- Period -} & \multirow{2}{*}{$\begin{array}{c}\text { Average } \\
\text { (both periods) }\end{array}$} & \multicolumn{2}{|c|}{ Manaqement } \\
\hline & & & & $\chi^{2}$ & $\mathrm{p}>\chi^{2}$ & & $\chi^{2}$ & $\mathrm{p}>\chi^{2}$ \\
\hline Conservation & Total parrotfish & $125.56 \pm 5.44$ & $102.7 \pm 10.97$ & 3.28 & NS & $121.48 \pm 4.93$ & 0.02 & NS \\
\hline General use & Total parrotfish & $140.9 \pm 12.95$ & $93.3 \pm 9.17$ & 5.98 & 0.01 & $131.28 \pm 10.65$ & & \\
\hline Conservation & Small parrotfish & $58.73 \pm 2.73$ & $48.55 \pm 5.43$ & 2.86 & NS & $56.91 \pm 2.46$ & 0.06 & NS \\
\hline General use & Small parrotfish & $67.87 \pm 6.5$ & $44.55 \pm 4.57$ & 5.94 & 0.01 & $63.16 \pm 5.34$ & & \\
\hline Conservation & Large parrotfish & $20.86 \pm 1.19$ & $15.25 \pm 1.59$ & 4.51 & 0.03 & $19.86 \pm 1.04$ & 2.09 & NS \\
\hline General use & Large parrotfish & $20.39 \pm 1.47$ & $12.95 \pm 1.12$ & 5.95 & 0.01 & $18.89 \pm 1.23$ & & \\
\hline Conservation & Grunts & $71.02 \pm 4.96$ & $230.3 \pm 92.56$ & 1.45 & NS & $99.46 \pm 17.66$ & 17.74 & $<0.0001$ \\
\hline General use & Grunts & $60.23 \pm 8.96$ & $52.55 \pm 8.39$ & 1.55 & NS & $58.68 \pm 7.34$ & & \\
\hline Conservation & Damselfish & $67.8 \pm 2.47$ & $60 \pm 4.98$ & 1.05 & NS & $66.41 \pm 2.23$ & 31.85 & $<0.0001$ \\
\hline General use & Damselfish & $90.73 \pm 3.46$ & $87.55 \pm 6.33$ & 0.28 & NS & $90.09 \pm 3.03$ & & \\
\hline Conservation & Wrasses & $49.82 \pm 2.27$ & $84.75 \pm 22.09$ & 0.39 & NS & $56.06 \pm 4.47$ & 0.003 & NS \\
\hline General use & Wrasses & $49.47 \pm 2.36$ & $53.4 \pm 6.17$ & 0.16 & NS & $50.26 \pm 2.25$ & & \\
\hline Conservation & Snappers & $21.76 \pm 2.21$ & $57.15 \pm 12.01$ & 15.47 & $<0.0001$ & $28.08 \pm 3.06$ & 44.46 & $<0.0001$ \\
\hline General use & Snappers & $8.15 \pm 0.92$ & $7.9 \pm 0.83$ & 1.20 & NS & $8.1 \pm 0.75$ & & \\
\hline Conservation & Surgeonfish & $20.82 \pm 1.41$ & $21.7 \pm 3.5$ & 0.001 & NS & $20.98 \pm 1.31$ & 6.26 & 0.01 \\
\hline General use & Surgeonfish & $15.99 \pm 1.04$ & $16.5 \pm 1.53$ & 0.36 & NS & $16.09 \pm 0.88$ & & \\
\hline Conservation & Piscivores & $10.6 \pm 0.96$ & $23.75 \pm 6.16$ & 11.46 & 0.001 & $12.95 \pm 1.42$ & 28.89 & $<0.0001$ \\
\hline General use & Piscivores & $7.03 \pm 0.93$ & $3.65 \pm 0.44$ & 1.30 & NS & $6.34 \pm 0.76$ & & \\
\hline Conservation & Butterflyfish & $3.57 \pm 0.25$ & $3.65 \pm 0.42$ & 0.34 & NS & $3.58 \pm 0.21$ & 1.22 & NS \\
\hline General use & Butterflyfish & $3.32 \pm 0.27$ & $3.2 \pm 0.39$ & 0.03 & NS & $3.29 \pm 0.23$ & & \\
\hline Conservation & Angelfish & $0.96 \pm 0.15$ & $2.9 \pm 0.58$ & 13.54 & 0.0002 & $1.31 \pm 0.17$ & 2.83 & NS \\
\hline General use & Angelfish & $0.82 \pm 0.17$ & $1.5 \pm 0.27$ & 8.65 & 0.003 & $0.96 \pm 0.15$ & & \\
\hline Conservation & Total & $451.51 \pm 9.44$ & $650.7 \pm 98.77$ & 4.04 & 0.04 & $487.08 \pm 20.26$ & 3.15 & NS \\
\hline General use & Total & $464.9 \pm 21.15$ & $377.05 \pm 16.16$ & 7.07 & 0.008 & $447.15 \pm 17.52$ & & \\
\hline \multicolumn{4}{|c|}{ Number of fish species, Term } & \multicolumn{2}{|c|}{ Estimate $\pm \mathrm{SE}$} & $t$ ratio & \multicolumn{2}{|l|}{ Prob $>[t]$} \\
\hline \multicolumn{4}{|l|}{ Intercept } & \multicolumn{2}{|r|}{$21.71 \pm 0.28$} & 76.72 & \multicolumn{2}{|l|}{$<0.0001$} \\
\hline \multicolumn{4}{|c|}{ Period[Post-ban] } & \multicolumn{2}{|r|}{$2.64 \pm 0.28$} & 9.32 & \multicolumn{2}{|l|}{$<0.0001$} \\
\hline \multicolumn{4}{|c|}{ Management[General use] } & \multicolumn{2}{|r|}{$-1.90 \pm 0.28$} & -6.70 & \multicolumn{2}{|l|}{$<0.0001$} \\
\hline \multicolumn{4}{|c|}{ Management[General use] ${ }^{*}$ Period[Post-ban] } & \multicolumn{2}{|r|}{$-0.45 \pm 0.28$} & -1.60 & \multicolumn{2}{|l|}{ NS } \\
\hline
\end{tabular}




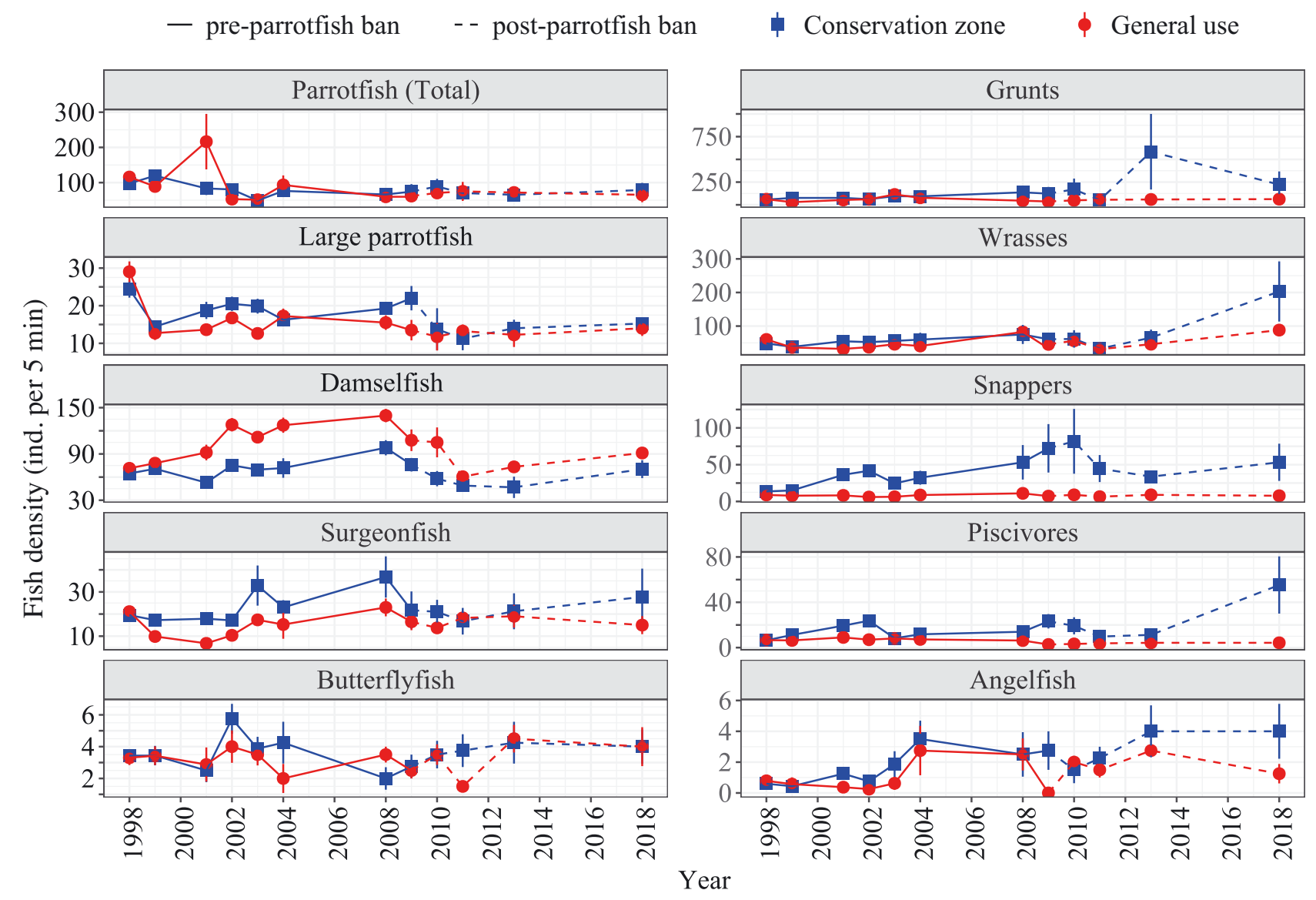

Fig. 2. Changes in the density of fish family/functional groups over the study period

The reserve management increased the abundance of targeted fished species, including bluestriped grunts Haemulon sciurus, blue tangs Acanthurus coeruleus, grey snapper Lutjanus griseus, yellowtail snapper Ocyurus chrysurus, lane snapper Lutjanus synagris, bar jacks Caranx ruber, schoolmaster Lutjanus apodus, jolthead porgy Calamus bajonado, great barracuda Sphyraena barracuda, queen angelfish Holocanthus ciliaris, mutton snapper Lutjanus analis, Nassau grouper Epinephelus striatus, hogfish Lachnolaimus maximus, black grouper Mycteroperca bonaci, and midnight parrotfish Scarus coelestinus (Table 2, Fig. 3b). Some unfished species that increased in the CZ were blue chromis Chromis cyanea and banded butterflyfish Chaetodon striatus. Grey angelfish Pomacanthus arcuatus were marginally more abundant in the GUZ than CZ.

After the ban, redband parrotfish Sparisoma aurofrenatum numbers declined in both the CZ and GUZ, while stoplight parrotfish Sparisoma viride declined in the CZ but not the GUZ. Redfin parrotfish Sparisoma rubripinne were not abundant; however, their densities increased in the $\mathrm{CZ}$ over the ban period but not in the GUZ. Small striped parrotfish densities did not change across the ban period. A number of nonparrotfish fished species increased in the $\mathrm{CZ}$ after the ban, including the yellowtail snapper, schoolmaster, mutton snapper, Nassau grouper, graysby Cephalopholis cruentata, and grey, queen, and French Pomacanthus paru angelfishes. Several targeted fished species decreased in the GUZ after the ban, including grey snapper, doctorfish Acanthurus chirurgus, jolthead porgy, queen angelfish, chub Kyphosus sectatrix, and ocean triggerfish Canthidermis sufflamen. Coney were not abundant but increased after the ban in the GUZ. Some unexpected changes occurred in unfished species in the GUZ, such as declines in yellowhead wrasse but increases in blue chromis, rainbow wrasse, rocky beauty, and the banded butterflyfish. Recruitment of 25 dominant fish species showed variable patterns (Fig. 5). The 3 parrotfish species recruited only before 2002. Other species, such as various species of wrasse, snapper, and grunt, all had recruitment periods after 2002 but with little evidence for synchrony among the taxa. 
a

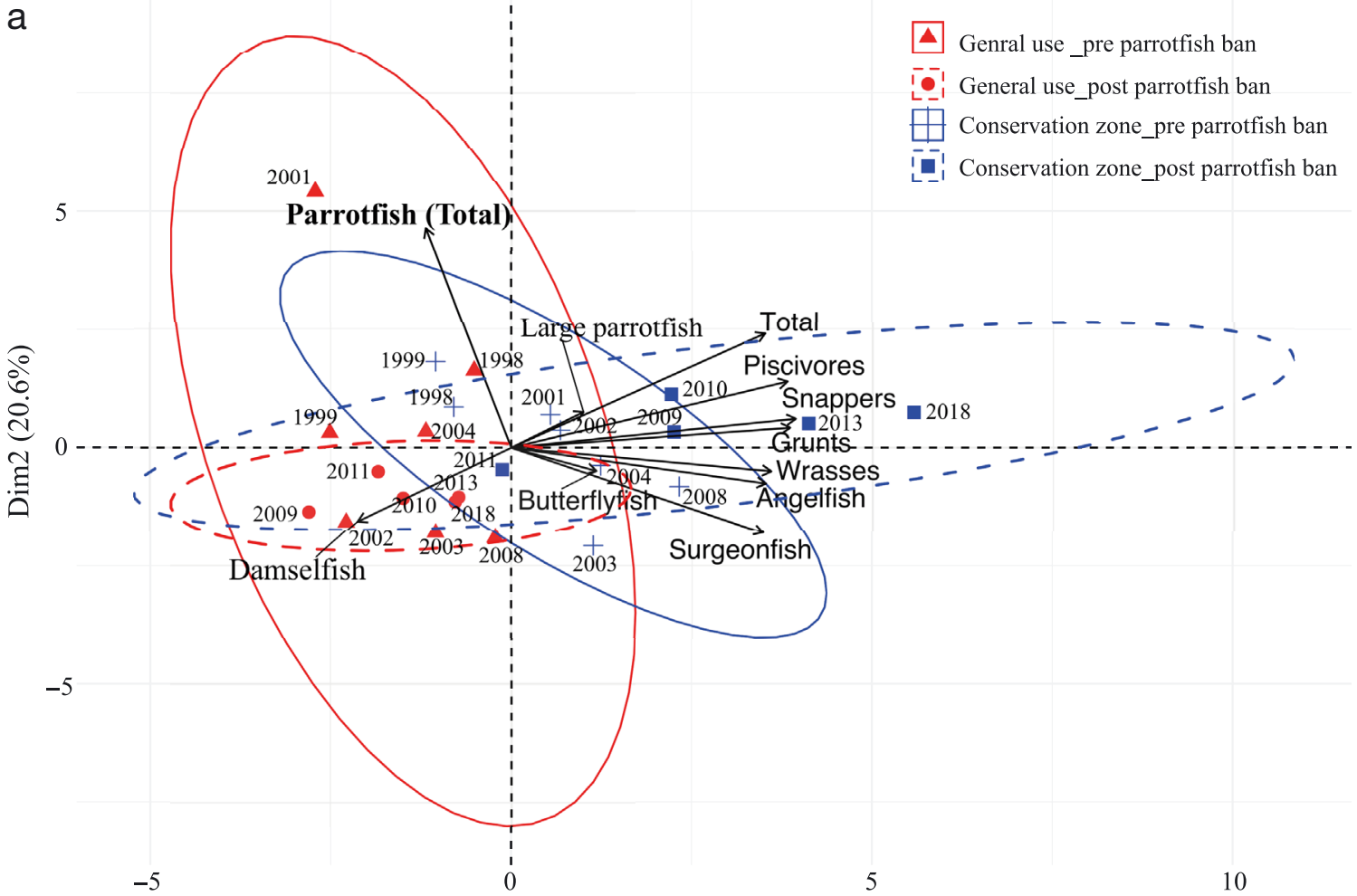

$\operatorname{Dim} 1(36.4 \%)$

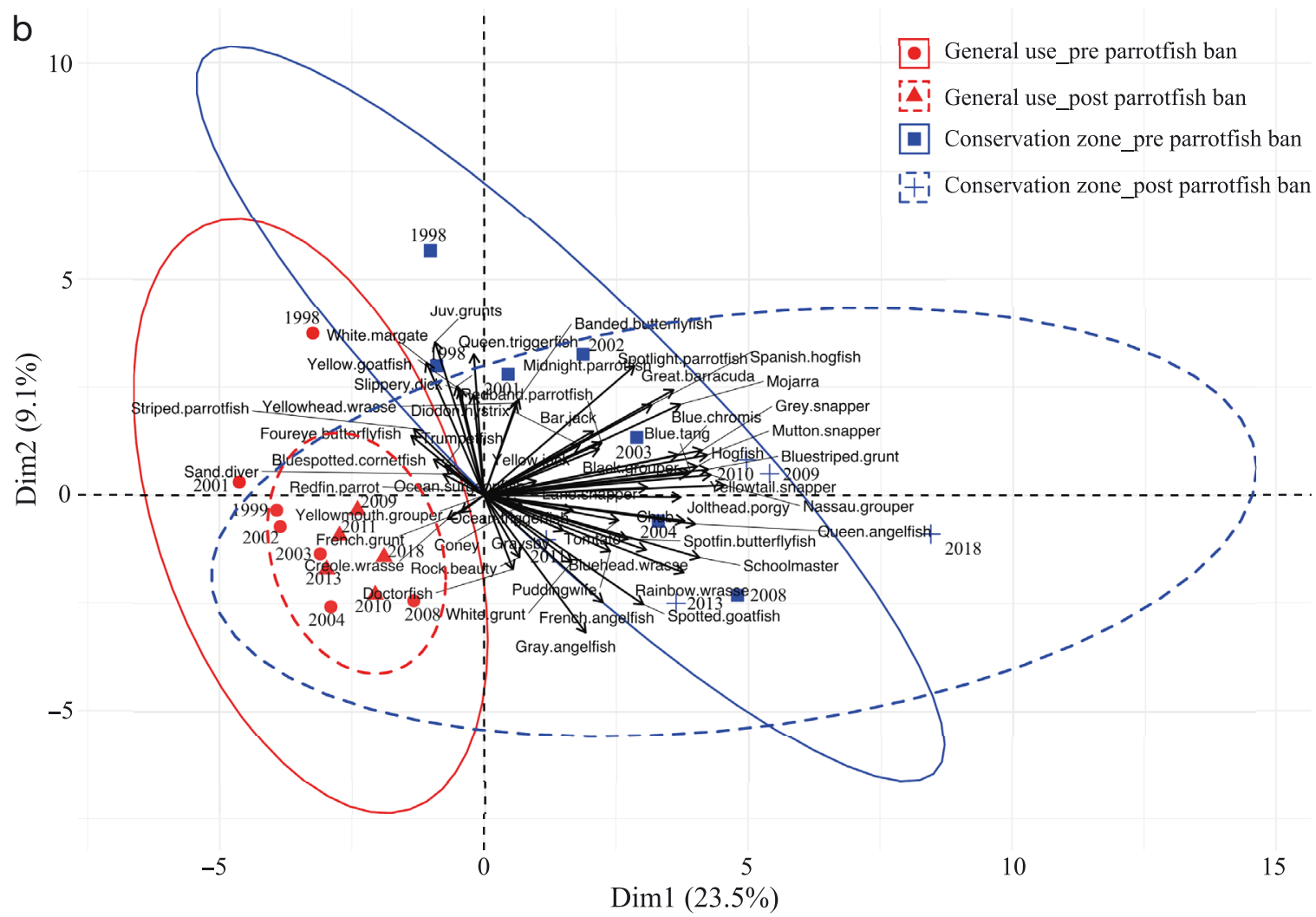

Fig. 3. Multivariate PCA analysis of fish grouped by (a) family/functional groups, and (b) genus/species 


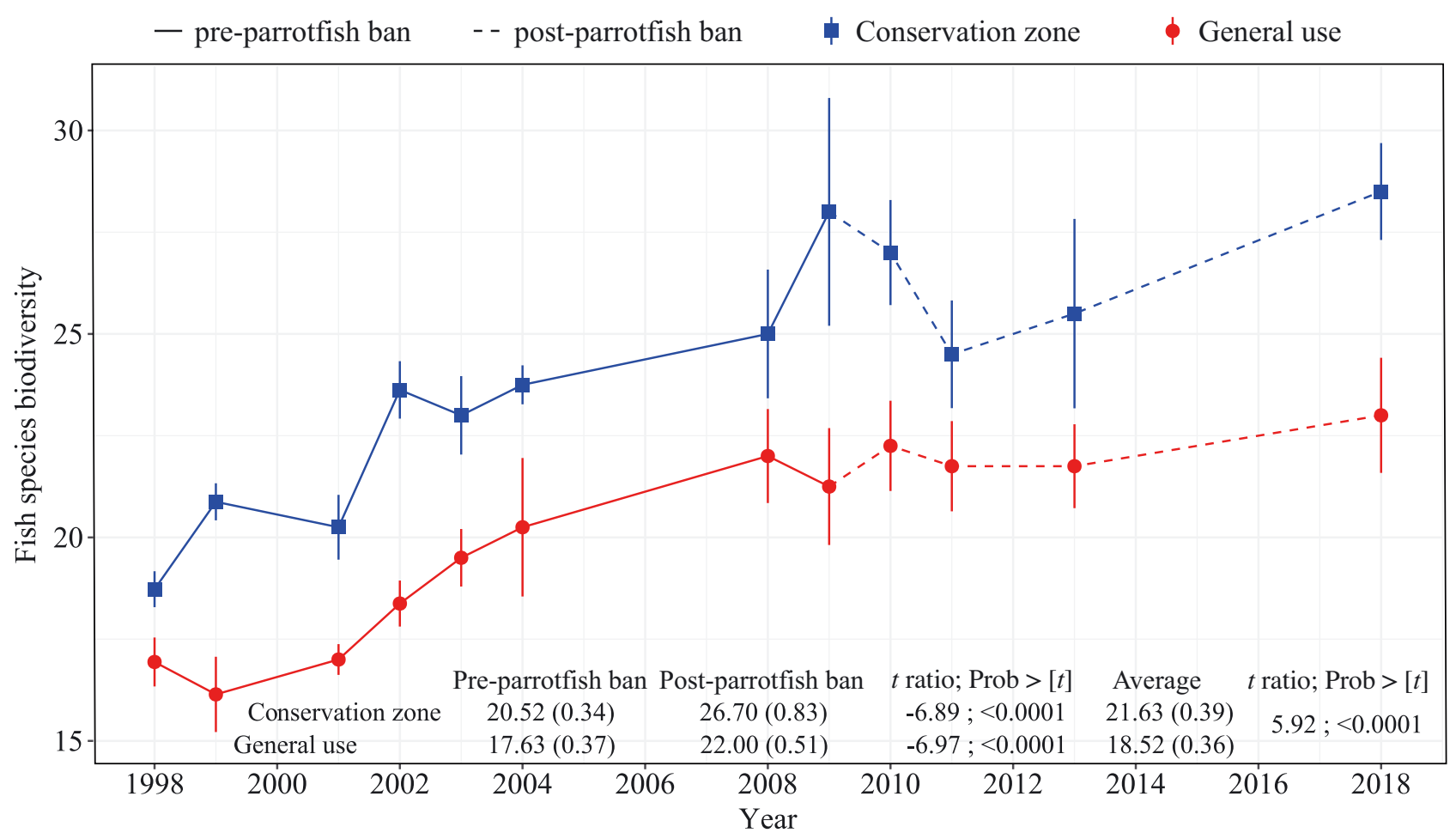

Fig. 4. Changes in total number of fish species observed over the 1998 to 2018 study period, including results of $t$-tests of differences between pre- and post-parrotfish capture ban in 2009, and Conservation and General Use Zones

\subsection{Herbivory}

Total herbivory, measured as total bite rates on assays, was not different between management zones (Table 3). There were, however, differences in bites attributable to fish and sea urchins, with higher herbivory by fish and lower herbivory by sea urchins in the CZ. Regardless, there were no differences in any bite rate metrics before and after the parrotfish ban. Time series plots indicate that herbivory by fish differed between the CZ and GUZ after 1999, when herbivory remained at $\sim 40 \%$ per day in the $\mathrm{CZ}$ but declined in the GUZ to $\sim 10-20 \%$ (Fig. 6). However, during the final sampling period in 2018, fish herbivory in the $\mathrm{CZ}$ declined considerably to $\sim 15 \%$ of the deployed assays. Sea urchin bite rates in the $\mathrm{CZ}$ remained low at $\sim 5 \%$ over the full time series. In the GUZ, however, sea urchin bite rates rose after 1996 and stayed between 10 to $20 \%$ of the assays until 2018.

\subsection{Benthic cover}

The main benthic cover functional groups displayed some changes in cover between management zones and periods (Table 4). Erect algae declined by about $9 \%$ after the ban in both the CZ and GUZ but hard coral cover remained unchanged. Turf and calcareous green algae were $(<2 \%)$ higher in the $\mathrm{CZ}$ than GUZ but did not change over time. Seagrass cover increased by $1.5 \%$ in the $\mathrm{CZ}$ after the ban but there were no differences between GUZ and CZ. Time-series plots indicate that the greatest increase in turf and erect algae occurred after 1998 when hard coral cover declined (Fig. 7). Turf algae responded first and increased before the erect algae, but turf algae eventually declined until 2009. Thereafter, turf algae increased and although erect algae fluctuated, it declined over time.

Hard coral cover dropped from 27 to $10 \%$ between 1996 and 2000 in the CZ but increased to $17 \%$ by 2018 (Fig. 7). The change in the coral cover in the GUZ was, however, less variable over time. A total of 24 genera were recorded and Orbicella annularis, Agaricia agaricites, Porites porites, Siderastrea siderea and $P$. asteroides contributed $87 \%$ of the coral cover. Comparison of the hard coral before and after the ban indicate increases of 33 and $23 \%$ in total cover in the $\mathrm{CZ}$ and GUZ, respectively. There was a mixture of increases and decreases at the species level (Table 5). In general, the dominant species increased while subdominant species decreased in both zones. 


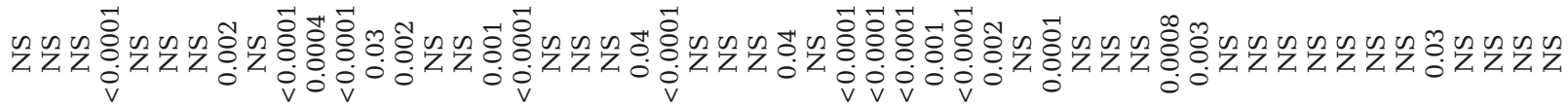
ذँ :

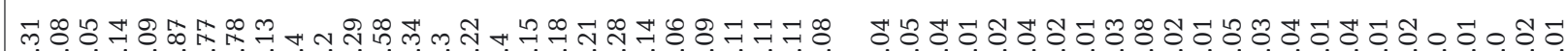
Whin $+1+1+1+1+1+1+1+1+1+1+1+1+1+1+1+1+1+1+1+1+1+1+1+1+1+1+1+1+1+1+1+1+1+1+1+1+1+1+1+1+1+1+1+1+1+1+1+1$

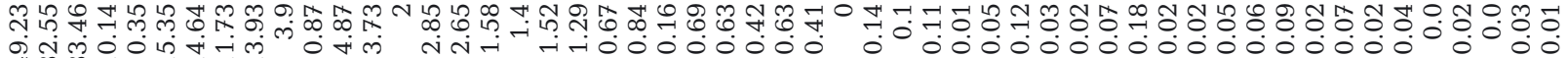

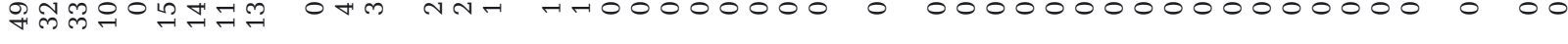

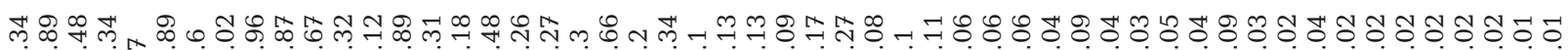

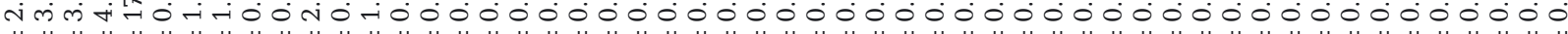

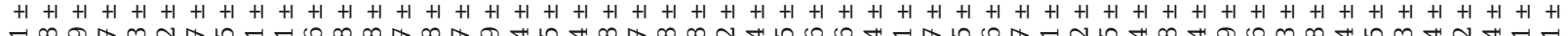

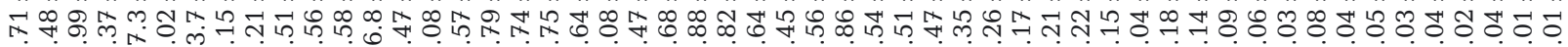

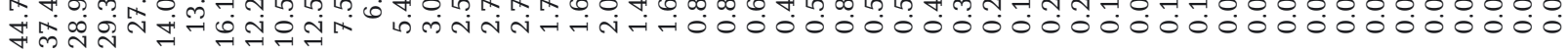

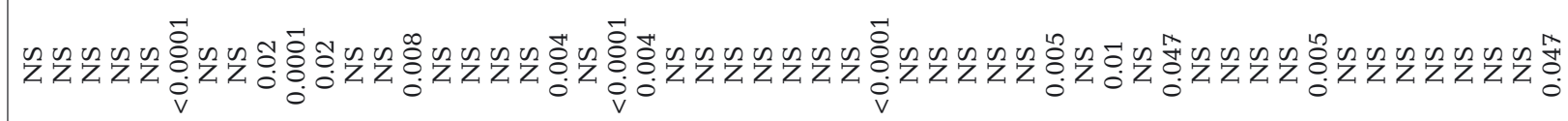

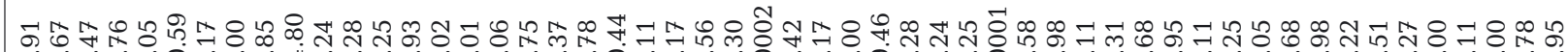
in

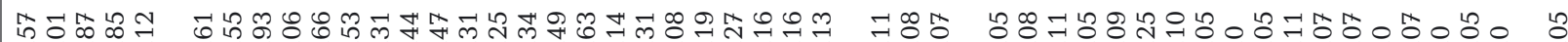

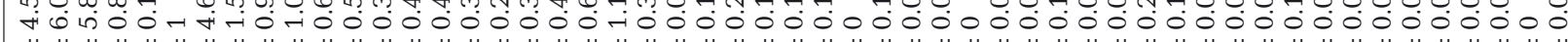
$+1+1+1+1+1+1+1+1+1+1+1+1+1+1+1+1+1+1+1+1+1+1+1+1+1+1+1+1+1+1+1+1+1+1+1+1+1+1+1+1+1+1+1+1+1+1+1+1+1+1+1+1+1$

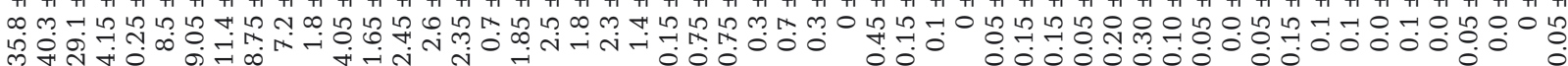

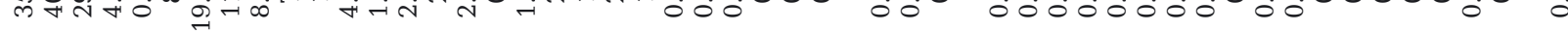

以 ט $+1+1+1+1+1+1+1+1+1+1+1+1+1+1+1+1+1+1+1+1+1+1+1+1+1+1+1+1+1+1+1+1+1+1+1+1+1+1+1+1+1+1+1+1+1+1+1+1+1+1+1+1+1$

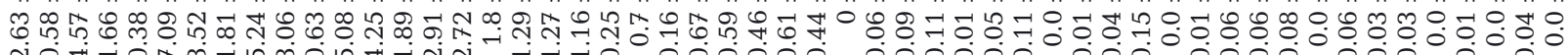
ஸि

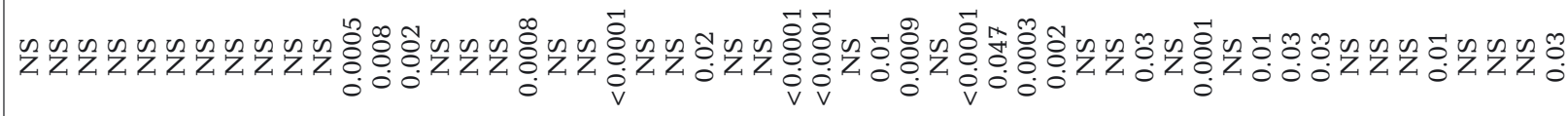

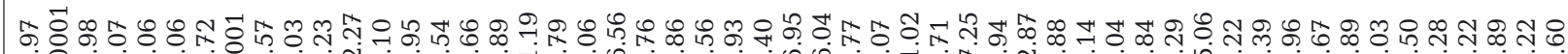

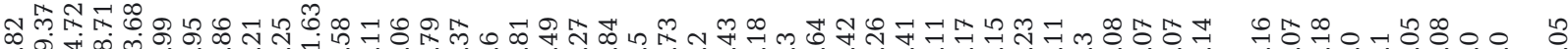

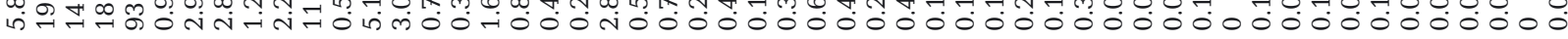
$+1+1+1+1+1+1+1+1+1+1+1+1+1+1+1+1+1+1+1+1+1+1+1+1+1+1+1+1+1+1+1+1+1+1+1+1+1+1+1+1+1+1+1+1+1+1+1+1+1+1+1+1+1$

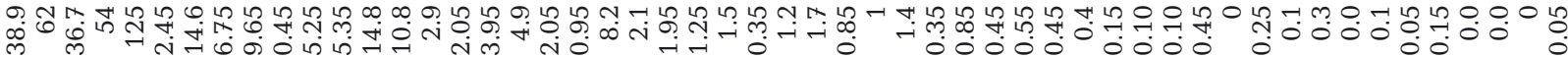

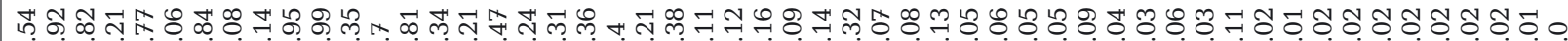
N-im-H-H H $+1+1+1+1+1+1+1+1+1+1+1+1+1+1+1+1+1+1+1+1+1+1+1+1+1+1+1+1+1+1+1+1+1+1+1+1+1+1+1+1+1+1+1+1+1+1+1+1+1+1+1+1+1$

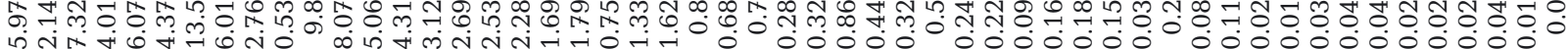
巾

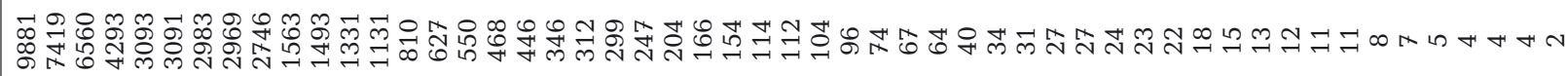

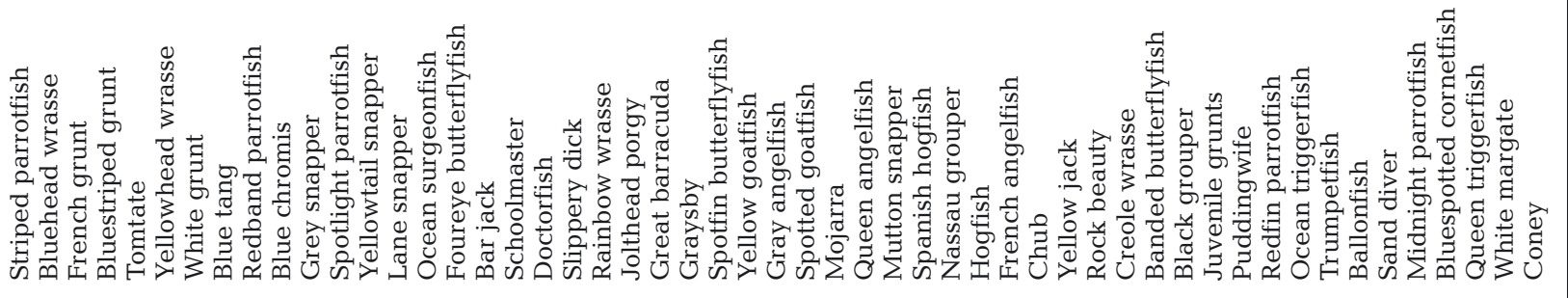




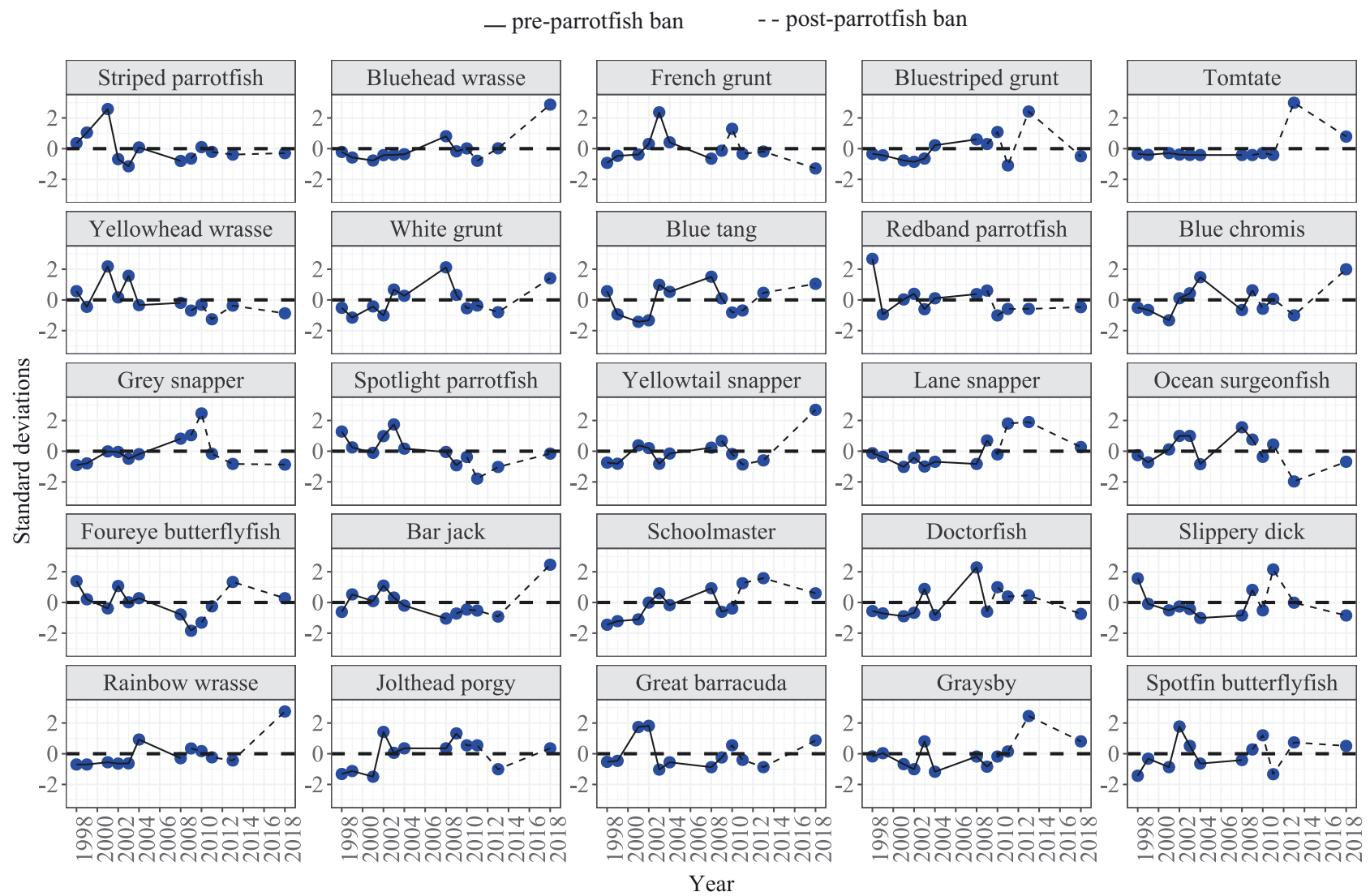

Fig. 5. Recruitment of dominant fish species in Glover's Reef atoll patch reefs $(n=8)$ over the study period, presented as variation (normalized standard deviations) from the full time series means

\section{DISCUSSION}

The $22 \mathrm{yr}$ time series indicates complex ecological responses to climate disturbances and fishing in these patch reefs. Nevertheless, the patch reefs were persistently dominated by algae, which increased particularly after the thermal stress and associated coral mortality events of 1998 and 2010. After the major 1998 disturbance, there was a rapid succession from turf to erect algae, with a slight decline in turf algae after erect algae increased, followed by another increase after 2010. Frondose erect algae maintained cover $>30 \%$ but also declined slightly after 1998 and more so after 2010. The CZ showed the greatest variability in hard coral cover, with a rapid decline in the early part of the time series and partial recovery after 2008. Thus, hard coral cover was most affected by the 1998 thermal stress and less by subsequent thermal stresses, largely due to the loss of Acropora spp. in 1998 and lack of recovery thereafter. Some of the dominant corals, such as $O$. annularis, A. agaricites, and $P$. porites, appeared to be increasing towards the

Table 3. Overall, fish, and sea urchin herbivory before and after the parrotfish capture ban period in the Conservation and General Use Zones of Glover's Reef. Data are mean \pm SE, and the results of Kruskal-Wallis tests comparing pre- and postcapture ban periods and management zones

\begin{tabular}{|c|c|c|c|c|c|c|c|c|}
\hline \multirow[t]{2}{*}{ Management } & \multirow{2}{*}{$\begin{array}{c}\text { Herbivory } \\
\text { type }\end{array}$} & \multirow{2}{*}{ Pre-ban } & \multirow{2}{*}{ Post-ban } & \multicolumn{2}{|c|}{ Period -} & \multirow{2}{*}{$\begin{array}{c}\text { Average } \\
\text { (both periods) }\end{array}$} & \multicolumn{2}{|c|}{ Management } \\
\hline & & & & $\chi^{2}$ & $\mathrm{p}>\chi^{2}$ & & $\chi^{2}$ & $\mathrm{p}>\chi^{2}$ \\
\hline Conservation zone & Total & $39.1 \pm 2.12$ & $38.31 \pm 3.63$ & 0.23 & NS & $38.89 \pm 1.82$ & 1.96 & NS \\
\hline General use & Total & $34.25 \pm 1.86$ & $32.98 \pm 2.86$ & 0.48 & NS & $33.9 \pm 1.56$ & & \\
\hline Conservation zone & Fish & $34.88 \pm 2.11$ & $33.19 \pm 3.63$ & 0.44 & NS & $34.43 \pm 1.82$ & 29.44 & $<0.0001$ \\
\hline General use & Fish & $21.49 \pm 1.82$ & $18.15 \pm 2.67$ & 2.07 & NS & $20.56 \pm 1.51$ & & \\
\hline Conservation zone & Sea urchin & $4.6 \pm 0.61$ & $5.47 \pm 1.04$ & 0.41 & NS & $4.84 \pm 0.52$ & 55.20 & $<0.0001$ \\
\hline General use & Sea urchin & $13.64 \pm 1.27$ & $15.16 \pm 1.84$ & 0.76 & NS & $14.06 \pm 1.05$ & & \\
\hline
\end{tabular}


Table 4. Percentage cover (mean \pm SE) of each functional group substrate type before and after the parrotfish capture ban in the Conservation and General Use Zones of Glover's Reef. The results of Kruskal-Wallis tests comparing pre- and post-capture ban periods and management zones are presented

\begin{tabular}{|c|c|c|c|c|c|c|c|c|}
\hline \multirow[t]{2}{*}{ Management } & \multirow[t]{2}{*}{ Substrate type } & \multirow[t]{2}{*}{ Pre-ban } & \multirow[t]{2}{*}{ Post-ban } & \multicolumn{2}{|c|}{- Period -} & \multirow{2}{*}{$\begin{array}{c}\text { Average } \\
\text { (both periods) }\end{array}$} & \multicolumn{2}{|c|}{ Management } \\
\hline & & & & $\chi^{2}$ & $\mathrm{p}>\chi^{2}$ & & $\chi^{2}$ & $\mathrm{p}>\chi^{2}$ \\
\hline Conservation & Erect frondose algae & $46.86 \pm 1.65$ & $37.08 \pm 2.81$ & 8.04 & 0.005 & $44.11 \pm 1.46$ & 0.10 & NS \\
\hline General use & Erect frondose algae & $46.69 \pm 1.54$ & $38.11 \pm 2.54$ & 7.24 & 0.007 & $44.2 \pm 1.35$ & & \\
\hline Conservation & Hard coral & $16.05 \pm 0.83$ & $16.88 \pm 1.23$ & 0.43 & NS & $16.28 \pm 0.69$ & 3.42 & NS \\
\hline General use & Hard coral & $17.48 \pm 0.7$ & $17.85 \pm 1.17$ & 0.04 & NS & $17.59 \pm 0.6$ & & \\
\hline Conservation & Turf algae & $9.43 \pm 0.6$ & $12.2 \pm 1.28$ & 2.60 & NS & $10.21 \pm 0.57$ & 8.01 & 0.005 \\
\hline General use & Turf algae & $8.08 \pm 0.68$ & $8.97 \pm 1.08$ & 0.47 & NS & $8.34 \pm 0.58$ & & \\
\hline Conservation & Coralline red algae & $7.73 \pm 0.43$ & $7.68 \pm 0.69$ & 0.07 & NS & $7.71 \pm 0.36$ & 0.009 & NS \\
\hline General use & Coralline red algae & $7.96 \pm 0.56$ & $8.4 \pm 0.75$ & 0.91 & NS & $8.09 \pm 0.45$ & & \\
\hline Conservation & Calcareous green algae & $6.13 \pm 0.47$ & $4.97 \pm 0.58$ & 1.77 & NS & $5.81 \pm 0.37$ & 4.70 & 0.03 \\
\hline General use & Calcareous green algae & $4.94 \pm 0.36$ & $4.06 \pm 0.48$ & 1.94 & NS & $4.68 \pm 0.29$ & & \\
\hline Conservation & Seagrass & $0.95 \pm 0.21$ & $2.49 \pm 0.49$ & 8.16 & 0.004 & $1.38 \pm 0.21$ & 0.17 & NS \\
\hline General use & Seagrass & $1.21 \pm 0.2$ & $1.38 \pm 0.33$ & 0.62 & NS & $1.26 \pm 0.17$ & & \\
\hline
\end{tabular}

end of the study but with simultaneous losses of Montastraea carvernosa, Diploria spp., and other rarer taxa. Calcifying red and green algae varied over time, showing some rises after coral mortality events but otherwise no clear relationship with disturbances and management. Thus, while erect algae declined after the parrotfish capture ban in 2009, this appeared to be part of a trend that began prior to the ban, as early as 2002. Moreover, while there was a modest rise in hard coral cover after the ban, this was not clearly attributable to the fisheries closure, the ban, or increases in parrotfish numbers. It is more likely a slow shift in the coral community was provoked by repeated thermal stresses.

The implementation of marine reserve in 1995 clearly increased populations of many fished species, but largely generalist carnivores and piscivores and not parrotfish. Snappers, in particular, showed a

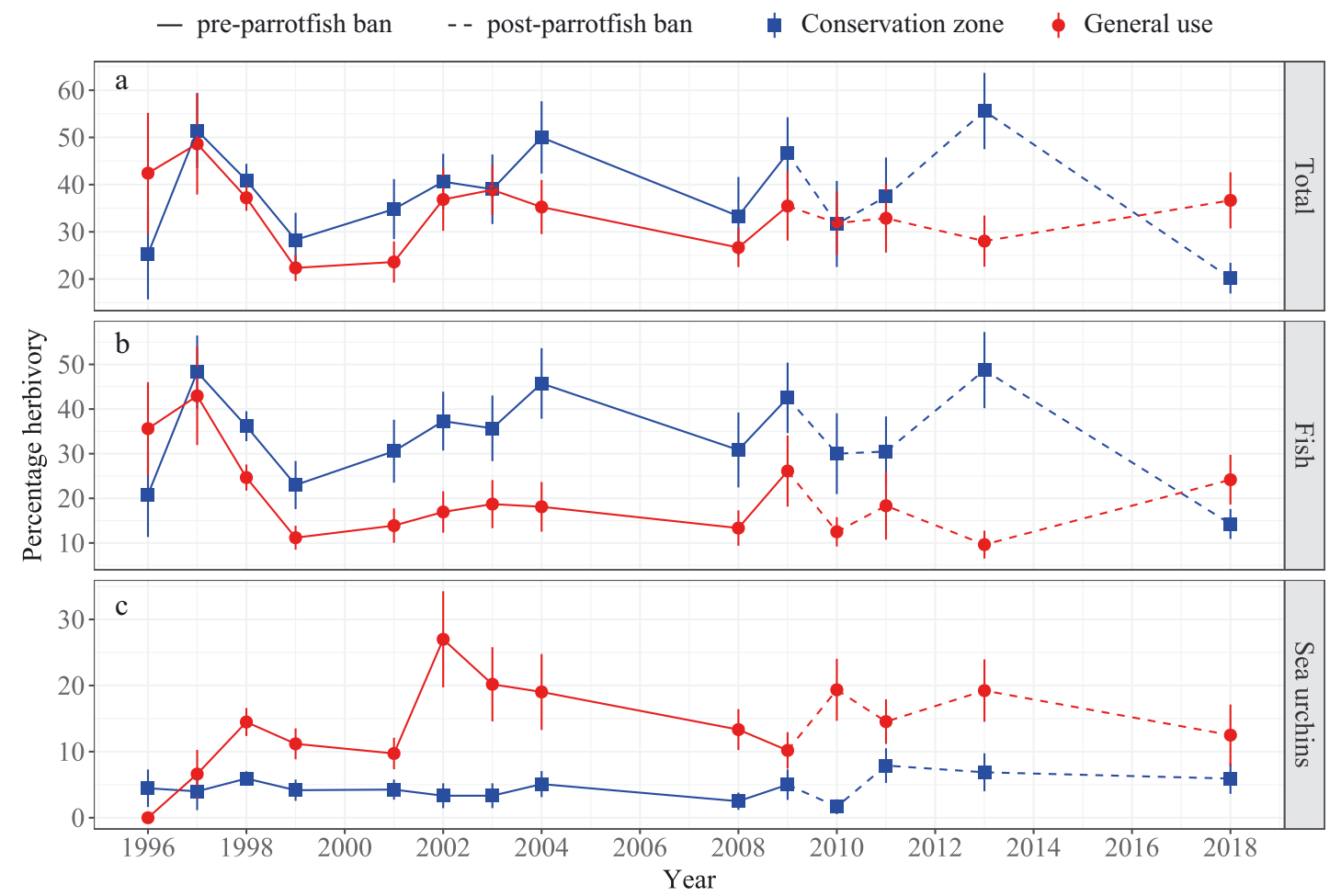

Fig. 6. Changes in (a) total herbivory, (b) herbivory attributable to fish, and (c) herbivory attributable to sea urchins in studied patch reefs over the study period. Herbivory is based on bites on a seagrass assay (see Section 2.4) 


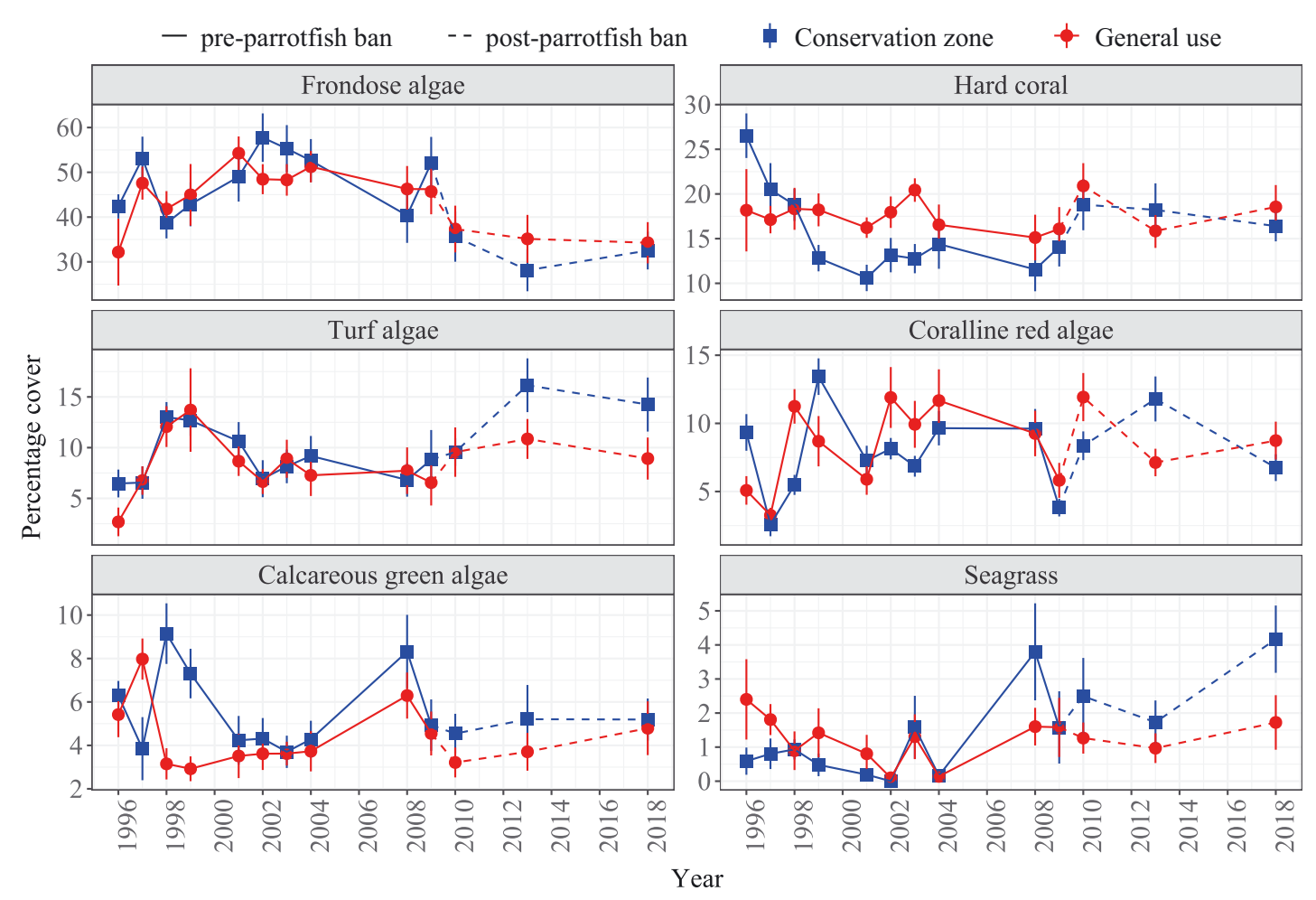

Fig. 7. Changes in benthic cover of the gross functional groups on the studied patch reefs over the study period

steady and consistent rise in numbers in the CZ that would be expected as a response to lower fishing mortality. Some increases in numbers, notably in black and Nassau groupers, continued past the first $10 \mathrm{yr}$ of closure. This explains the greater changes in the $\mathrm{CZ}$ after the parrotfish capture ban, rather than some potential indirect or immigration effect from the ban. Parrotfish numbers, on the other hand, appeared to decline slowly over time with no evidence for an effect of the capture ban on their numbers. This decline occurred for small as well as large parrotfish, suggesting some shared ecological rather than fishing effect. The decline appeared to be a slow process that was not reversed by the single high recruitment peak of parrotfish observed in 2001. The failure of parrotfish recruitment after 2002 was not observed in other species and therefore unlikely to be driven by environmental factors shared by all species.

Bite rates on the seagrass assay indicate an early rise and stabilization of herbivory in the $\mathrm{CZ}$, while a steady decline was observed in the GUZ associated with continued fishing. Bite rate maintenance in the CZ was, however, not evident at the end of the study, 9 yr after the ban. Patterns of herbivory are more likely to be explained by the sizes of the parrotfish, rather than their numbers. Parrotfish in the $\mathrm{CZ}$, while not increasing in numbers, did maintain their sizes or grow larger over time, while body sizes declined in the GUZ (T. R. McClanahan pers. obs.). The early rise in bite rates in the $\mathrm{CZ}$ is likely due to this increase in the size of targeted parrotfish rather than numbers. Fishing pressure is a better predictor of body size differences than population densities, as consistently reported for Caribbean parrotfish (Vallès \& Oxenford 2014, Vallès et al. 2015). The lack of recruitment of parrotfish in the CZ over the full study period is likely what failed to produce the expected rise. At the end of the study, fish bite rates declined and this may be due to the long-term lack of net recruitment and consequent loss of larger parrotfish over the $22 \mathrm{yr}$ period. Consequently, the evidence indicates that parrotfish populations and their expected impacts on algae and corals were controlled by factors other than fishing. One consistent trend in herbivory was a rise and levelling in bite rates by sea urchins within the GUZ. All of these changes occurred within the context of an early rise and levelling in the number of fish species in both the CZ and GUZs during the first decade of the closure.

The trophic model of fishing impacts on herbivory and subsequent control of coral-algal relationships was not consistently supported. The findings here suggest that other ecological processes influence these patch reefs, which limits the model's ability to predict outcomes of management interventions, as reported in other large-scale studies (Russ et al. 2015, 
Table 5. Percent cover (mean \pm SE) and the percentage change for individual coral species and overall before (2004-2009) and after (2010-2018) the parrotfish capture ban in the Conservation and General Use Zones of Glover's Reef. Taxa are arranged in descending order of percent cover in the Conservation Zone before the parrotfish capture ban period

\begin{tabular}{|c|c|c|c|c|c|c|}
\hline \multirow[t]{2}{*}{ Coral taxa } & \multicolumn{3}{|c|}{ - Conservation zone coral cover $(\%)$} & \multicolumn{3}{|c|}{ General use coral cover $(\%)$} \\
\hline & $2004-2009$ & 2010-2018 & $\begin{array}{c}\text { Percentage } \\
\text { change }\end{array}$ & 2004-2009 & 2010-2018 & $\begin{array}{c}\text { Percentage } \\
\text { change }\end{array}$ \\
\hline Orbicella annularis & $3.81 \pm 0.00$ & $4.32 \pm 0.00$ & 11.85 & $5.86 \pm 0.00$ & $6.66 \pm 0.00$ & 12.13 \\
\hline Agaricia agaricitis & $2.72 \pm 0.42$ & $3.61 \pm 0.64$ & 24.58 & $2.34 \pm 0.44$ & $3.02 \pm 0.63$ & 22.72 \\
\hline Porites porites & $1.96 \pm 0.40$ & $3.85 \pm 0.62$ & 49.12 & $2.69 \pm 0.47$ & $3.65 \pm 0.57$ & 26.39 \\
\hline Siderastrea siderea & $1.80 \pm 0.47$ & $1.33 \pm 0.31$ & -36.08 & $1.95 \pm 0.49$ & $2.83 \pm 0.58$ & 31.27 \\
\hline Porites asteroides & $1.18 \pm 0.24$ & $1.51 \pm 0.21$ & 22.13 & $0.91 \pm 0.21$ & $1.63 \pm 0.27$ & 44.32 \\
\hline Diploria strigosa & $0.60 \pm 0.28$ & $0.76 \pm 0.30$ & 20.58 & $0.39 \pm 0.17$ & $0.59 \pm 0.27$ & 34.22 \\
\hline Millepora complanata & $0.40 \pm 0.12$ & $0.60 \pm 0.28$ & 32.86 & $0.11 \pm 0.07$ & $0.21 \pm 0.12$ & 47.14 \\
\hline Millepora alcicornis & $0.28 \pm 0.11$ & $1.60 \pm 0.36$ & 82.47 & $0.69 \pm 0.20$ & $0.58 \pm 0.17$ & -19.44 \\
\hline Montastraea cavernosa & $0.23 \pm 0.17$ & $0.00 \pm 0.00$ & -100 & $0.14 \pm 0.12$ & $0.10 \pm 0.08$ & -36.02 \\
\hline Diploria clivosa & $0.15 \pm 0.15$ & $0.09 \pm 0.06$ & -71.76 & $0.20 \pm 0.09$ & $0.07 \pm 0.07$ & -175.42 \\
\hline Diploria labyrinth & $0.08 \pm 0.05$ & $0.00 \pm 0.00$ & -100 & $0.12 \pm 0.09$ & $0.03 \pm 0.03$ & -346.29 \\
\hline Dichocoenia stokesi & $0.05 \pm 0.05$ & $0.00 \pm 0.00$ & -100 & $0.00 \pm 0.00$ & $0.00 \pm 0.00$ & 0.00 \\
\hline Mussa angulosa & $0.03 \pm 0.03$ & $0.05 \pm 0.05$ & 31.42 & $0.00 \pm 0.00$ & $0.00 \pm 0.00$ & 0.00 \\
\hline Eusmilia fastigiata & $0.02 \pm 0.02$ & $0.05 \pm 0.03$ & 48.08 & $0.00 \pm 0.00$ & $0.05 \pm 0.05$ & 100 \\
\hline Acropora palmata & $0.02 \pm 0.02$ & $0.00 \pm 0.00$ & -100 & $0.00 \pm 0.00$ & $0.09 \pm 0.09$ & 100 \\
\hline Colpophyllia natans & $0.02 \pm 0.02$ & $0.00 \pm 0.00$ & -100 & $0.00 \pm 0.00$ & $0.00 \pm 0.00$ & 0.00 \\
\hline Favia fragum & $0.01 \pm 0.01$ & $0.00 \pm 0.00$ & -100 & $0.06 \pm 0.02$ & $0.00 \pm 0.00$ & -100 \\
\hline Manicina areolata & $0.00 \pm 0.00$ & $0.00 \pm 0.00$ & 0.00 & $0.04 \pm 0.03$ & $0.00 \pm 0.00$ & -100 \\
\hline Scolymia & $0.00 \pm 0.00$ & $0.00 \pm 0.00$ & 0.00 & $0.01 \pm 0.01$ & $0.00 \pm 0.00$ & -100 \\
\hline Acropora cervicornis & $0.00 \pm 0.00$ & $0.00 \pm 0.00$ & 0.00 & $0.23 \pm 0.16$ & $0.00 \pm 0.00$ & -100 \\
\hline Porites colonensis & $0.00 \pm 0.00$ & $0.00 \pm 0.00$ & 0.00 & $0.00 \pm 0.00$ & $0.00 \pm 0.00$ & 0.00 \\
\hline Agaricia tenuifolia & $0.00 \pm 0.00$ & $0.02 \pm 0.02$ & 100 & $0.00 \pm 0.00$ & $0.09 \pm 0.07$ & 100 \\
\hline Porites branneri & $0.00 \pm 0.00$ & $0.00 \pm 0.00$ & 0.00 & $0.00 \pm 0.00$ & $0.00 \pm 0.00$ & 0.00 \\
\hline Stephanocoenia michelini & $0.00 \pm 0.00$ & $0.03 \pm 0.03$ & 100 & $0.00 \pm 0.00$ & $0.02 \pm 0.02$ & 100 \\
\hline Total & $13.36 \pm 1.13$ & $17.77 \pm 1.59$ & 33.01 & $15.74 \pm 1.60$ & $19.62 \pm 1.94$ & 23.13 \\
\hline
\end{tabular}

McClanahan \& Muthiga 2016, Bruno et al. 2019). Specifically, coral cover and sensitive taxa appeared to be more influenced by thermal stress and background environmental conditions and secondarily by interactions with algae (Williams et al. 2001, McClanahan et al. 2011b). Similarly, parrotfish numbers appeared to be more influenced by environmental or ecological forces rather than by fishing mortality. Fishing impacts are more likely to influence fish sizes and biomass and have short-term effects while fish densities may have long-term effects, especially when net recruitment fails (Skinner et al. 2019). The influence of recruitment failure and abundance was shown for both small and large parrotfish, where small parrotfish acted as a control for fishing mortality for the larger species. Given that a number of ecological factors are not well understood, the outcomes of parrotfish capture bans are potentially difficult to predict. Better understanding the environmental and habitat factors that limit and interact with parrotfish populations will therefore be critical to understanding the outcomes of managing parrotfish.

Parrotfish biomass has been shown to respond to reduced fishing mortality either through fisheries clo- sures or changes in fishing effort and gear (McClanahan et al. 2007, Vallès \& Oxenford 2014, O'Farrell et al. 2015). The rates of response can vary considerably and possibly be influenced by the variable or slow life history characteristics of some of the species (McClanahan \& Humphries 2012, Taylor et al. 2014). In the case of a ban in Bermuda, the biomass of parrotfish recovered but without an increase in juvenile recruitment (O'Farrell et al. 2015). Thus, recruitment failures over time could result in long-term biomass declines, as we observed here. We observed high recruitment prior to 2002, which was followed by recruitment failures that suggest poor environmental conditions for parrotfish recovery. We also found that small striped parrotfish declined along with the larger-bodied stoplight and red-band parrotfish, suggesting that the species' maximum lengths and life histories were not a major influence. Nevertheless, the larger-bodied midnight, rainbow Scarus guacamaia, and blue parrotfish Scarus coeruleus were seldom or never observed in this habitat, suggesting some species-specific associations with the patch reef habitats and associated limitations determined by life historyenvironment interactions (Mumby et al. 2004). 
Ecological and environmental conditions were more likely than fishing to have played a role in limiting these parrotfish species. The conditions in this lagoon are calm, and the weak physical current and wave forces (current speeds $<10 \mathrm{~cm} \mathrm{~s}^{-1}$ ) are likely to be structuring these communities (McClanahan \& Karnauskas 2011, McClanahan et al. 2011b). This may be one reason why erect algae is so persistent, as algal succession is seldom arrested or reversed by strong waves, currents, and storms that periodically or seasonally impact reefs and remove late-successional algae (Vuki \& Price 1994, Clifton 1995). In fact, coral growth in the southern end of the atoll has been shown to be more limited by water flow than the presence of erect algae (McClanahan et al. 2011b). Therefore, one explanation for the declines in parrotfish is that the environment is increasingly antagonistic for their recovery.

Striped parrotfish feeding, growth, and reproduction studies in Panamanian reefs found a positive association between the renewal rates of algae and parrotfish growth and reproduction rates (Clifton 1995). In the Florida Keys, parrotfish preference for turf algae increased with turf cover and, therefore, fleshy algae was not controlled by parrotfish biomass (Smith et al. 2018). Experimental reductions of algae in Glover's Reef patch reefs increased herbivorous fish numbers and feeding rates, mostly for the blue tang, but also the stoplight parrotfish (McClanahan et al. 2000). Thus, these lines of evidence suggest that slow renewal rates of algae could influence parrotfish feeding choices and impede feeding rates and population growth. Low current and wave energy and associated disturbances in the patch reefs are likely to produce low algal renewal rates, particularly in the southern portion of the atoll where currents are slow (McClanahan \& Karnauskas 2011). Thermal stress and coral bleaching conditions are particularly stressful in these reef lagoons and therefore caused changes and losses of some rare and sensitive coral species over time (McClanahan \& Muthiga 1998). If so, declining current strength would reduce algal renewal rates and promote declining parrotfish growth, reproduction, and recruitment, as well as their subsequent ability to control algae. The proposed algal renewal hypothesis could provide an important area of study to better understand limits on parrotfish populations.

Controlling reef algae is increasingly being understood as an interaction between the diversity of herbivore life histories, feeding rates, habitat requirements, and temporal and spatial patterns of animal movements and feeding (Mumby et al. 2004, Bonaldo et al. 2012, Thibaut et al. 2012, Humphries et al. 2014, Lef- check et al. 2019, Ruttenberg et al. 2019). Thus, our patch reefs are likely to be an environment that fails to provide the conditions for effective herbivory and associated ecological stability. These reefs cannot, therefore, maintain the early successional or heavily grazed states that promote coral recruitment and recovery (O'Leary et al. 2012). Consequently, banning the capture of parrotfish is unlikely to reverse ongoing ecological changes that impede parrotfish recovery. Outside of hurricane affected reefs, low algal renewal environments may be increasing in the Caribbean and therefore promoting the dominance of late-succession algae. Interestingly, the number of species of fish increased after the CZ was established, while parrotfish diversity remained low. Low parrotfish diversity in these patch reefs is possibly associated with the lack of extensive mangrove forests on Glover's Reef atoll. This critical habitat can limit recruitment of some parrotfish species, notably those species not observed on patch reefs (Mumby et al. 2004).

Banning the capture of parrotfish was not clearly associated with increased mortality of other fish species or, at least, not detectable at our sites using our methods. Rather, there was some stability in angelfish and increases in chub abundances that might not be expected from the ban. It was clear that the reserve was protecting species and that the sizes of targeted species, such as angelfish, were smaller where they were fished. However, after $9 \mathrm{yr}$, it was not clear whether the ban had reduced the recruitment of alternative less-preferred target species whose capture might be promoted by the parrotfish ban. In contrast, there is some evidence that the reserve is supporting fisheries yields and preventing further and faster declines of targeted species where fishing occurs (Acosta 2002, Bond et al. 2012, Tewfik et al. 2017).

Banning the capture of parrotfish, either through marine reserves or fisheries regulations, is one of the few options for fisheries managers. Given the increasingly hostile conditions for hard corals and beneficial conditions for algae, it is advisable to maintain these management options. The outcomes of parrotfish bans are, however, likely to vary with the ecological forces and habitats of the reefs. Environments that promote algal renewal and habitat diversity (i.e. mangroves) are likely to promote herbivore populations and diversity in the absence of fishing mortality. Consequently, our study does not suggest a widespread failure of the ban but rather adds to the variety of potential responses, such as habitat-specific impacts. Therefore, management via banning is not a panacea for restoration of populations independent of other controlling factors (Bozec et al. 2016). The 
marine reserve has been effective in preventing the decline and supporting the recovery of species that require long recovery periods (Acosta 2002, Bond et al. 2012, Babcock et al. 2013, Tewfik et al. 2017). However, some taxa, such as parrotfish, will require approaches that better consider habitats and other factors that are not always considered important in their distributions (Roff et al. 2019). The marine reserve is located at the southern end of the atoll and most of the fishing closure areas are located where current speeds are lowest. One would expect higher algal renewal rates elsewhere - in tidal channels, reef crests and slopes, and the northern portions of the atoll (McClanahan \& Karnauskas 2011). If recovery and protection of parrotfish is a priority, then these are better habitats for promoting their recovery.

Acknowledgements. We are grateful to the Belize Fisheries Department for permission to undertake this work in the reserve, and for their field and logistic assistance. The Wildlife Conservation Society (WCS) supported the research via The Middle Caye Research Facility. Many people assisted with this fieldwork, including V. Alamina, A. C. Baker, A. R. Bulnes, V. Burns, A. Cansino, E. Cantun, T. Clarke, B. Cokos, M. DiLorenzo, A. Eck, S. Jones, S. Novelo, M. Phillips, M. Nunez, D. Pietri, E. Sala, P. Stickels, A. Tilley, F. Villanueva, and D. Wesby. J. Kosgei assisted with the production of figures and tables.

\section{LITERATURE CITED}

Acosta CA (2002) Spatially explicit dispersal dynamics and equilibrium population sizes in marine harvest refuges. J Mar Sci 59:458-468

Adam TC, Burkepile DE, Ruttenberg BI, Paddack MJ (2015) Herbivory and the resilience of Caribbean coral reefs: knowledge gaps and implications for management. Mar Ecol Prog Ser 520:1-20

Adam TC, Duran A, Fuchs CE, Rojas MC, Ruttenberg BI, Burkepile DE (2018) Comparative analysis of foraging behavior and bite mechanics reveals complex functional diversity among Caribbean parrotfishes. Mar Ecol Prog Ser 597:207-220

Babcock EA, Coleman R, Karnauskas M, Gibson J (2013) Length-based indicators of fishery and ecosystem status: Glover's Reef Marine Reserve, Belize. Fish Res 147: 434-445

Beck HJ, Feary DA, Figueira WF, Booth DJ (2014) Assessing range shifts of tropical reef fishes: a comparison of belt transect and roaming underwater visual census methods. Bull Mar Sci 90:705-721

Bellwood DR, Hughes TP, Folke C, Nystrom M (2004) Confronting the coral reef crisis. Nature 429:827-833

Bonaldo RM, Welsh JQ, Bellwood DR (2012) Spatial and temporal variation in coral predation by parrotfishes on the GBR: evidence from an inshore reef. Coral Reefs 31: 263-272

Bond ME, Babcock EA, Pikitch EK, Abercrombie DL, Lamb NF, Chapman DD (2012) Reef sharks exhibit site-fidelity and higher relative abundance in marine reserves on the
Mesoamerican Barrier Reef. PLOS ONE 7:e32983

* Bozec YM, O'Farrell S, Bruggemann JH, Luckhurst BE, Mumby PJ (2016) Tradeoffs between fisheries harvest and the resilience of coral reefs. Proc Natl Acad Sci USA 113:4536-4541

* Bruno JF, Precht WF, Vroom PS, Aronson RB (2014) Coral reef baselines: How much macroalgae is natural? Mar Pollut Bull 80:24-29

* Bruno JF, Côté IM, Toth LT (2019) Climate change, coral loss, and the curious case of the parrotfish paradigm: Why don't marine protected areas improve reef resilience? Annu Rev Mar Sci 11:307-334

Clifton KE (1995) Asynchronous food availability on neighboring Caribbean coral reefs determines seasonal patterns of growth and reproduction for the herbivorous parrotfish Scarus iserti. Mar Ecol Prog Ser 116:39-46

* Cox CE, Jones CD, Wares JP, Castillo KD, McField MD, Bruno JF (2013) Genetic testing reveals some mislabeling but general compliance with a ban on herbivorous fish harvesting in Belize. Conserv Lett 6:132-140

Cox C, Valdivia A, McField M, Castillo K, Bruno JF (2017) Establishment of marine protected areas alone does not restore coral reef communities in Belize. Mar Ecol Prog Ser 563:65-79

*Darling ES, McClanahan TR, Maina J, Gurney GG and others (2019) Social-environmental drivers inform strategic management of coral reefs in the Anthropocene. Nat Ecol Evol 3:1341-1350

De Bakker DM, Van Duyl FC, Bak RP, Nugues MM, Nieuwland G, Meesters EH (2017) 40 years of benthic community change on the Caribbean reefs of Curaçao and Bonaire: the rise of slimy cyanobacterial mats. Coral Reefs 36: 355-367

Eakin CM, Morgan JA, Heron SF, Smith TB and others (2010) Caribbean corals in crisis: record thermal stress, bleaching, and mortality in 2005. PLOS ONE 5:e13969

Edmunds PJ, Adjeroud M, Baskett ML, Baums IB and others (2014) Persistence and change in community composition of reef corals through present, past, and future climates. PLOS ONE 9:e107525

Government of Belize (2009) Statutory instrument no. 49 of 2009. Fisheries (Nassau grouper and species protection) regulations. Government of Belize

Hay ME (1984) Patterns of fish and urchin grazing on Caribbean coral reefs: Are previous results typical? Ecology 65:446-454

*Humphries AT, McClanahan TR, McQuaid CD (2014) Differential impacts of coral reef herbivores on algal succession in Kenya. Mar Ecol Prog Ser 504:119-132

*Huntington BE, Karnauskas M, Babcock EA, Lirman D (2010) Untangling natural seascape variation from marine reserve effects using a landscape approach. PLOS ONE 5:e12327

Lefcheck JS, Innes-Gold AA, Brandl SJ, Steneck RS, Torres RE, Rasher DB (2019) Tropical fish diversity enhances coral reef functioning across multiple scales. Sci Adv 5: eaav6420

* Legendre P, Gallagher ED (2001) Ecologically meaningful transformations for ordination of species data. Oecologia 129:271-280

McClanahan TR, Humphries A (2012) Differential and slow life-history responses of fishes to coral reef closures. Mar Ecol Prog Ser 469:121-131

* McClanahan TR, Karnauskas M (2011) Relationships between benthic cover, current strength, herbivory, and a 
fisheries closure in Glovers Reef Atoll, Belize. Coral Reefs 30:9-19

McClanahan TR, Muthiga NA (1998) An ecological shift in a remote coral atoll of Belize over 25 years. Environ Conserv 25:122-130

McClanahan TR, Muthiga NA (2016) Similar impacts of fishing and environmental stress on calcifying organisms in Indian Ocean coral reefs. Mar Ecol Prog Ser 560:87-103

* McClanahan TR, Nugues M, Mwachireya S (1994) Fish and sea urchin herbivory and competition in Kenyan coral reef lagoons: the role of reef management. J Exp Mar Biol Ecol 184:237-254

McClanahan TR, Bergman K, Huitric M, McField M, Elfwing T, Nystrom M, Nordemar I (2000) Response of fishes to algal reductions on Glovers Reef, Belize. Mar Ecol Prog Ser 206:273-282

McClanahan TR, McField M, Huitric M, Bergman K and others (2001) Responses of algae, corals and fish to the reduction of macroalgae in fished and unfished patch reefs of Glovers Reef Atoll, Belize. Coral Reefs 19:367-379

McClanahan T, Polunin N, Done T (2002) Ecological states and the resilience of coral reefs. Conserv Ecol 6:18

McClanahan TR, Graham NAJ, Calnan JM, MacNeil MA (2007) Toward pristine biomass: reef fish recovery in coral reef marine protected areas in Kenya. Ecol Appl 17: 1055-1067

* McClanahan TR, Muthiga NA, Coleman RA (2011a) Testing for top-down control: Can post-disturbance fisheries closures reverse algal dominance? Aquat Conserv 21:658-675

* McClanahan TR, Huntington BE, Cokos B (2011b) Coral responses to macroalgal reduction and fishery closure on Caribbean patch reefs. Mar Ecol Prog Ser 437:89-102

Mumby PJ (2009) Phase shifts and the stability of macroalgal communities on Caribbean coral reefs. Coral Reefs 28: 761-773

Mumby PJ, Edwards AJ, Arias-González JE, Lindeman KC and others (2004) Mangroves enhance the biomass of coral reef fish communities in the Caribbean. Nature 427:533-536

*Muñiz-Castillo AI, Rivera-Sosa A, Chollett I, Eakin CM, Andrade-Gómez L, McField M, Arias-González JE (2019) Three decades of heat stress exposure in Caribbean coral reefs: a new regional delineation to enhance conservation. Sci Rep 9:11013

Newman MJ, Paredes GA, Sala E, Jackson JB (2006) Structure of Caribbean coral reef communities across a large gradient of fish biomass. Ecol Lett 9:1216-1227

* O'Farrell S, Harborne AR, Bozec YM, Luckhurst BE, Mumby PJ (2015) Protection of functionally important parrotfishes increases their biomass but fails to deliver enhanced recruitment. Mar Ecol Prog Ser 522:245-254

*'Leary JK, Potts DC, Braga JC, McClanahan TR (2012) Indirect consequences of fishing: Reduction of coralline algae suppresses juvenile coral abundance. Coral Reefs 31:547-559

*Pawlik JR, Burkepile DE, Thurber RV (2016) A vicious circle? Altered carbon and nutrient cycling may explain the low resilience of Caribbean coral reefs. BioScience 66: 470-476

*Perry CT, Murphy GN, Graham NA, Wilson SK, Januchowski-Hartley FA, East HK (2015) Remote coral reefs can sustain high growth potential and may match future sea-level trends. Sci Rep 5:18289

Rasher DB, Engel S, Bonito V, Fraser GJ, Montoya JP, Hay

Editorial responsibility: Stephen Wing,

Dunedin, New Zealand
ME (2012) Effects of herbivory, nutrients, and reef protection on algal proliferation and coral growth on a tropical reef. Oecologia 169:187-198

Roff G, Mumby PJ (2012) Global disparity in the resilience of coral reefs. Trends Ecol Evol 27:404-413

Roff G, Bejarano S, Priest M, Marshell A and others (2019) Seascapes as drivers of herbivore assemblages in coral reef ecosystems. Ecol Monogr 89:e01336

* Russ GR, Questel SLA, Rizzari JR, Alcala AC (2015) The parrotfish-coral relationship: refuting the ubiquity of a prevailing paradigm. Mar Biol 162:2029-2045

* Ruttenberg BI, Adam TC, Duran A, Burkepile DE (2019) Identity of coral reef herbivores drives variation in ecological processes over multiple spatial scales. Ecol Appl 29:e01893

* Siegel KJ, Cabral RB, McHenry J, Ojea E, Owashi B, Lester SE (2019) Sovereign states in the Caribbean have lower social-ecological vulnerability to coral bleaching than overseas territories. Proc R Soc B 286:20182365

* Skinner C, Newman SP, Box S, Narozanski A, Polunin NV (2019) Chronic spearfishing may indirectly affect reef health through reductions in parrotfish bite rates. J Fish Biol 94:585-594

Smith KM, Quirk-Royal BE, Drake-Lavelle K, Childress MJ (2018) Influences of ontogenetic phase and resource availability on parrotfish foraging preferences in the Florida Keys, FL (USA). Mar Ecol Prog Ser 603:175-187

Steneck RS, Mumby PJ, MacDonald C, Rasher DB, Stoyle G (2018) Attenuating effects of ecosystem management on coral reefs. Sci Adv 4:eaao5493

* Suchley A, Alvarez-Filip L (2018) Local human activities limit marine protection efficacy on Caribbean coral reefs. Conserv Lett 11:e12571

* Suchley A, McField MD, Alvarez-Filip L (2016) Rapidly increasing macroalgal cover not related to herbivorous fishes on Mesoamerican reefs. PeerJ 4:e2084

Taylor BM, Houk P, Russ GR, Choat JH (2014) Life histories predict vulnerability to overexploitation in parrotfishes. Coral Reefs 33:869-878

*Tewfik A, Babcock EA, Gibson J, Perez VRB, Strindberg S (2017) Benefits of a replenishment zone revealed through trends in focal species at Glover's Atoll, Belize. Mar Ecol Prog Ser 580:37-56

Thibaut LM, Connolly SR, Sweatman HPA (2012) Diversity and stability of herbivorous fishes on coral reefs. Ecology 93:891-901

* Toth LT, van Woesik R, Murdoch TJT, Smith SR, Ogden JC, Precht WF, Aronson RB (2014) Do no-take reserves benefit Florida's corals? 14 years of change and stasis in the Florida Keys National Marine Sanctuary. Coral Reefs 33: 565-577

Vallès H, Oxenford HA (2014) Parrotfish size: a simple yet useful alternative indicator of fishing effects on Caribbean reefs? PLOS ONE 9:e86291

* Vallès H, Gill D, Oxenford HA (2015) Parrotfish size as a useful indicator of fishing effects in a small Caribbean island. Coral Reefs 34:789-801

* Vuki VC, Price IR (1994) Seasonal changes in the Sargassum populations on a fringing coral reef, Magnetic Island, Great Barrier Reef region, Australia. Aquat Bot 48:153-166

Williams ID, Polunin VC, Hendrick VJ (2001) Limits to grazing by herbivorous fishes and the impact of low coral cover on macroalgal abundance on a coral reef in Belize. Mar Ecol Prog Ser 222:187-196

Submitted: February 13, 2020; Accepted: May 5, 2020 Proofs received from author(s): June 20, 2020 